\title{
Analisis Penggunaan Label Halal pada Produk Kecantikan Brand Safi dalam Menarik Minat Beli Masyarakat
}

\author{
Jesslyn, Eko Harry Susanto \\ Jesslyn.915150018@stu.untar.ac.id,ekos@fikom.untar.ac.id \\ Fakultas Ilmu Komunikasi Universitas Tarumanagara
}

\begin{abstract}
In this era of increasingly fierce competition, one way to get loyal consumers is to satisfy consumer needs consistently over time. Absolutely the same thing must be done by beauty product companies. Please note that $87.2 \%$ of Indonesia's population is Moslem. This situation makes halal products become one of the important things that must be considered by many beauty product companies. This situation encourages and creates the presence of beauty products to have halal labels such as Safi in Indonesia. The purpose of this research was to analyze the use of halal labels on Safi beauty products in attracting people's buying interest. This research is qualitative research by using phenomenology methods. The concept used in this research is the perception inside communication psychology theory. The cultural theory is also used in this research. Data collection method in this research use interviews with women in Jakarta who apply beauty products, literature studies, and online data researches. The results of this research are that people still have difficulty in finding products that have a halal label, also the Safi beauty products have not been well known by the public and the use of halal labels on Safi beauty products attracts people's buying interest.
\end{abstract}

Keywords: Halal Label, Beauty Product, Safi, Buying Interest

\begin{abstract}
Abstrak
Di era persaingan yang semakin ketat ini, salah satu cara untuk mendapatkan konsumen yang loyal adalah dengan memuaskan kebutuhan konsumen secara konsisten dari waktu ke waktu. Sama halnya yang harus dilakukan oleh para perusahaan produk kecantikan. Perlu diketahui bahwa $87.2 \%$ penduduk Indonesia adalah penganut agama Islam. Hal ini membuat kehalalan produk merupakan salah satu bagian penting yang harus diperhatikan oleh sejumlah perusahaan. Hal ini tentu mendorong hadirnya produk kecantikan memiliki label halal seperti brand Safi di Indonesia. Tujuan penelitian ini adalah menganalisis penggunaan label halal pada produk kecantikan brand Safi dalam menarik minat beli masyarakat.Penelitian ini merupakan penelitian kualitatif dengan menggunakan metode fenomenologi. Konsep yang digunakan dalam penelitian ini adalah persepsi dalam teori psikologi komunikasi. Adapun teori budaya juga digunakan dalam penelitian ini. Pengumpulan data dalam penelitian ini menggunakan wawancara dengan perempuan Jakarta yang menggunakan produk kecantikan, studi pustaka dan juga penelusuran data online. Hasil dari penelitian ini adalah masyarakat mengalami kesulitan dalam mencari produk yang memiliki label halal, produk kecantikan brand Safi belum terlalu dikenal oleh masyarakat dan penggunaan label halal pada produk kecantikan brand Safi menarik minat beli masyarakat.
\end{abstract}

Kata Kunci: Label Halal, Produk Kecantikan, Brand Safi, Minat Beli 


\section{Pendahuluan}

Manusia merupakan makhluk yang akan selalu membutuhkan orang lain dalam menjalankan aktvitias sehari-hari. Manusia sering sekali disebut makhluk sosial karena selalu berinteraksi dengan manusia lain untuk memenuhi kebutuhan. Untuk memenuhi kebutuhan, manusia memperlukan komunikasi yang baik dan benar. Komunikasi adalah suatu proses transmisi, komunikasi merupakan pentransferan pemahaman, proses untuk menghubungkan satu entitas dengan entitas lain, komunikasi merupakan saluran untuk mengirimkan pesan, tindakan mengeluarkan stimulus untuk memperoleh respon. Komunikasi juga merupakan proses atensi menjadi ingatan dan komunikasi memiliki maksud untuk mendorong munculnya perilaku (Susanto, 2010:4).

Dikutip bedasarkan proyeksi pertumbuhan penduduk oleh Badan Perencanaan Pembangunan Nasional, Badan Pusat Statistik dan United Nations Population Fund di tahun 2018, jumlah penduduk Indonesia sebanyak 265 juta jiwa dan 131,88 juta diantaranya berjenis kelamin perempuan. Menurut kelompok umur terdapat 86,75 juta jiwa yang berumur 20-64 tahun (https://databoks.katadata.co.id/datapublish/2018/05/18/2018-jumlah-pendudukindonesia-mencapai-265-juta-jiwa diakses pada 2 September 2018). Perlu diketahui bahwa $87.2 \%$ penduduk Indonesia adalah penganut agama Islam. Hal ini membuat kehalalan produk merupakan salah satu kebutuhan penting yang harus diperhatikan oleh sejumlah perusahaan. Umat muslim sangat dilarang untuk mengkonsumsi produk yang mengandung bahan-bahan tidak halal.

Seperti yang sudah di atur dalam Undang-Undang (UU) No. 33 Tahun 2014 tentang Jaminan Produk Halal (JPH). Produk pangan, obat serta kosmetik harus dicantumkan keterangan-keterangan yang berhubungan dengan ulasan produk. Keterangan tersebut biasanya berupa komposisi bahan campuran, masa berlaku produk, cara penggunaan dan keterangan bahwa produk telah diperiksa oleh Badan Pengawasan Pangan, Obat dan Kosmetik (BPPOM).

Label halal diperoleh setelah mendapatkan sertifikat halal. Sertifikat halal adalah fatwa tertulis Majelis Ulama Indonesia (MUI) yang menyatakan kehalalan suatu produk sesuai dengan syari'at Islam. Sertifikat Halal MUI ini merupakan syarat untuk mendapatkan ijin pencantuman label halal pada kemasan produk dari instansi pemerintah yang berwenang. Tujuan sertifikasi halal adalah sertifikasi halal MUI pada produk pangan, obat-obat, kosmetika dan produk lainnya dilakukan untuk memberikan kepastian status kehalalan, sehingga dapat menenteramkan batin konsumen dalam mengkonsumsinya (http://www.halalmui.org/mui14/index.php/main/go_to_section/55/1360/page/1 diakses pada tanggal 16 Oktober 2018).

Label halal merupakan salah satu bagian dari simbol tanda alamiah yang merupakan bagian dari dunia fisik digunakan secara spontan dan tidak sengaja dalam merespon stimuli. Dimana makna simbol secara sembarang dipilih dan berdasarkan kesepakatan yang tidak memiliki hubungan kausal dengan apa yang direpresentasikannya (Sobur, 2017: 163)

Hal ini membuat berbagai perusahaan salah satunya perusahan produk kecantikan berusaha memenuhi kebutuhan para perempuan muslim Indonesia dengan melakukan inovasi dari berbagai macam produk. Menurut Kotler produk merupakan segala sesuatu yang dapat ditawarkan kepada pasar agar menarik perhatian, akuisisi, penggunaan, atau konsumsi yang dapat memuaskan suatu keinginan atau kebutuhan 
(Kotler dan Keller, 2016:390). Produk perawatan kulit atau skincare product memiliki tujuan yang baik untuk kulit yaitu, mempertahankan serta meningkatkan kesehatan dan juga fungsi kulit lainnya. Sehingga membuat para kaum perempuan membutuhkan sekali produk-produk ini dan membuat mereka tetap tampil cantik dan percaya diri dalam kehidupan sehari-hari.

Merek adalah nama, istilah, simbol atau rancangan, atau kombinasi hal-hal tersebut yang dimaksud konsumen untuk mengidentifikasi barang atau jasa dari seseorang atau kelompok penjual dan untuk membedakannya dari pesaing. Merekmerek yang kuat akan memberikan jaminan kualitas dan nilai yang tinggi kepada pelanggan, yang akhirnya juga akan berdampak luas terhadap perusahaan (Kotler 2009:332). Merek yang akan dibahas pada penelitian ini adalah Safi. Produk skincare khusus dirancang untuk perempuan muslim yang memiliki keinginan memakai produk kecantikan tanpa mengandung bahan berbahaya serta sudah bersertifikasi halal. Produk Safi sudah bersertifikasi halal dari Jabatan Kemajuan Islam Malaysia (JAKIM) dan Majelis Ulama Indonesia (MUI).

Penelitian ini menganalisis penggunaan label halal pada produk kecantikan brand Safi dalam menarik minat beli masyarakat. Seperti yang dikatakan Kotler dan Keller bahwa minat beli adalah sebuah perilaku konsumen dimana konsumen mempunyai keinginan untuk membeli atau memilih suatu produk berdasarkan pengalaman dalam memilih, menggunakan, dan mengkonsumsi atau bahkan menginginkan suatu produk (Bernardinus, 2016: 24).

Penelitian ini memiliki tujuan untuk mengetahui apa alasan produk halal sulit ditemukan, brand Safi belum dikenal masyarakat dan melihat penggunaan label halal pada produk kecantikan brand Safi dalam menarik minat beli masyarakat.

\section{Metode Penelitian}

Penelitian ini dilakukan dengan metode penelitian kualitatif. Menurut Lexy J. Moleong pendekatan penelitian kualitatif adalah penelitian yang bermaksud untuk memahami fenomena tentang apa yang dialami oleh subjek penelitian misalnya perilaku, persepsi, motivasi, tindakan dan lainnya secara holistik dengan cara deskripsi dalam bentuk kata-kata dan bahasa pada suatu konteks khusus yang alamiah dengan memanfaatkan berbagai metode alamiah (Moleong,2013: 6).

Moustakas mengatakan (dalam Creswell, 2012:20-21) bahwa fenomenologi merupakan strategi penelitian di mana di dalamnya peneliti mengidentifikasi hakikat pengalaman manusia tentang suatu fenomena tertentu.

Metode yang pengumpulan data yang digunakan pada penelitian ini adalah wawancara mendalam sebagai data primer dan penelusuran data online sebaga data sekuner.

Menurut Muri Yusuf wawancara merupakan salah satu teknik yang dapat digunakan untuk mengumpulkan data penelitian. Wawancara dapat diartikan sebagai percakapan tatap muka antara pewawancara dengan sumber informasi tentang objek yang diteliti dengan pertanyaan yang sudah dirancang sebelumnya (Yusuf, 2014:372).

Penelusuran data online adalah tata cara melakukan penelusuran data melalui media online seperti internet atau media jaringan lainnya yang menyediakan fasilitas online sehingga memungkinkan peneliti dapat memanfaatkan data informasi online yang berupa data maupun informasi teori secepat atau semudah mungkin dan dapat dipertanggungjawabkan secara akademis (Bungin, 2011:128). 


\section{Hasil Temuan dan Diskusi}

Tidak heran jika produk kecantikan selalu dicari oleh para kaum perempuan. Produk kecantikan sudah tidak asing lagi bagi perempuan di Jakarta. Produk kecantikan brand Safi adalah produk yang sudah lebih dari 30 tahun berkembang di Malaysia dan sekarang hadir untuk perempuan Indonesia. Produk kecantikan ini merupakan produk kecantikan yang mengedepankan halal, natural dan teruji. Pada penelitian ini peneliti menganalisis penggunaan label halal pada produk kecantikan brand Safi dalam menarik minat beli masyarakat. Berikut merupakan hasil yang didapatkan oleh peneliti:

\section{Produk Label Halal Sulit Ditemukan}

Dalam memilih produk kecantikan banyak sekali kendala serta pertimbangan yang dilakukan oleh perempuan. Pertimbangan dan alasannya pun terdapat berbagai macam. Setiap individu tentu memiliki pemikiran tersendiri untuk memilih produk seperti apa yang mereka inginkan dan yang mereka butuhkan.

Banyak sekali pilihan produk kecantikan yang ada ternyata tidak memudahkan kaum perempuan dalam memilih serta menggunakan produk kecantikan. Salah satu masalah yang ditemukan dalam memilih produk kecantikan adalah sulitnya menemukan produk yang memiliki label halal, khususnya produk kecantikan.

Tabel 1 Produk Label Halal Sulit Ditemukan

\begin{tabular}{ll}
\hline Keterangan & \multicolumn{2}{c}{ Penjelasan } \\
\hline Produk Label Halal Sulit Ditemukan & Produk kecantikan yang sedang tren \\
& masa kini di Indonesia merupakan \\
& produk kecantikan asal dari Korea \\
& yang tentu tidak memperhatikan label \\
& halal. Sehingga membuat label halal \\
& sekarang ini menjadi sangat sulit \\
& untuk ditemukan. \\
& Ketidak pekaannya beberapa \\
& perusahaan produk kecantikan \\
& terhadap kandungan yang digunakan \\
& dalam produk kecantikan. \\
& Perusahaan produk kecantikan \\
& cenderung lebih memperhatikan hasil \\
& yang diberikan. \\
& Label Halal tidak bisa di dapatkan \\
& dengan mudah, sebuah produk \\
kecantikan jika ingin mencatumkan & label halal harus lulus melalui tes uji \\
kandungan serta proses pembuatan \\
yang kompleks dan panjang \\
prosesnya.
\end{tabular}

Sumber: Diolah oleh peneliti 
Berbagai pernyataan yang dikemukakan oleh narasumber bahwa produk yang memiliki label halal sulit ditemukan khususnya di Indonesia. Banyak faktor yang memicu sulitnya menemukan produk kecantikan memiliki label halal. Dengan hal ini sangat disayangkan bagi produk kecantikan terutama skincare yang tidak memiliki label halal.

\section{Masyarakat Belum Mengenal Brand Safi}

Di Indonesia sudah terdapat berbagai macam brand produk kecantikan, lebih dari 10 (sepuluh) brand yang ada di Indonesia baik brand lokal maupun brand luar. Salah satu contoh brand produk kecantikan yang ada di Indonesia adalah Safi.

Safi yang merupakan produk yang berasal dari Safi Research Institute berpusat di Malaysia. Brand Safi merupakan produk kecantikan yang rilis di Indonesia pada 23 Febuari 2018. Walaupun sudah berada di Indonesia kurang lebih hampir setahun, brand Safi masih belum dikenal oleh masyarakat dengan berbagai alasan yang dijalaskan dengan tabel berikut:

Tabel 2 Masyarakat Belum Mengenal Brand Safi

\begin{tabular}{cl}
\hline Keterangan & \multicolumn{1}{c}{ Penjelasan } \\
\hline $\begin{array}{c}\text { Masyarakat } \\
\text { Belum Mengenal } \\
\text { Brand Safi }\end{array}$ & $\begin{array}{l}\text { Produk kecantikan brand Safi sedikit melakukan iklan } \\
\text { di media konvensional seperti TV atau radio sehingga } \\
\text { membuat masyarakat terutara perempuan Jakarta tidak }\end{array}$ \\
& $\begin{array}{l}\text { terlalu mengenal dengan produk kecantikan baru } \\
\text { tersebut. }\end{array}$ \\
& $\begin{array}{l}\text { Rendahnya brand awareness perempuan Jakarta } \\
\text { terhadap produk kecantikan Safi. } \\
\text { Porduk kecantikan brand Safi merupakan sebuah brand } \\
\text { produk baru di Indonesia yang tidak terlalu banyak } \\
\text { diperbicarakan. }\end{array}$
\end{tabular}

\section{Sumber: Diolah oleh Peneliti}

Penjelasan di atas membuktikan bahwa brand Safi dari awal muncul hingga penelitian ini dilakukan masih banyak perempuan yang belum mengenal produk ini. Brand skincare Safi merupakan produk halal yang cukup baru jika dibandingkan produk kecantikan yang memiliki label halal lainnya.

\section{Label Halal Menarik Minat Beli Masyarakat}

Dicantumkannya label halal pada sebuah produk kecantikan menjadi sebuah pertanyaan. Apakah label halal tersebut menarik minat beli masyarakat atau hanya menjadi sebuah formalitas belaka. Muncul berbagai jawaban yang diberikan oleh narasumber atas pertanyaan tentang label halal yang diulas penjelasannya pada tabel berikut menurut jawaban narasumber: 
Tabel 3 Pernyataan Masyarakat Pada Label Halal Produk Kecantikan Brand Safi

\begin{tabular}{cl}
\hline Pernyataan & \multicolumn{1}{c}{ Penjelasan } \\
\hline $\begin{array}{c}\text { Label Halal pada produk } \\
\text { kecantikan brand Safi } \\
\text { menarik minat beli } \\
\text { masyarakat }\end{array}$ & $\begin{array}{l}\text { Perempuan Jakarta merasa terbantu adanya } \\
\text { label halal yang dicantumkan oleh Safi }\end{array}$ \\
& $\begin{array}{l}\text { Research Institute. } \\
\text { kecantikan brand Safi membuat perempuan } \\
\text { Jemilih percaya dengan produk ini dalam }\end{array}$ \\
& tentunya menarik minat. \\
& \multicolumn{1}{c}{ Perempuan Jakarta percaya dengan produk } \\
kecantikan yang memiliki label halal karena \\
teruji memiliki kandungan yang aman \\
sehingga membuat mereka memilih produk \\
kecantikan Safi sebagai produk yang mereka \\
gunakan sehari-hari.
\end{tabular}

\section{Sumber: Diolah Oleh Peneliti}

Banyak alasan yang diberikan oleh para pengguna produk kecantikan brand Safi yang memiliki label halal. Dengan menekankan halal, natural dan teruji tentu membuat perempuan Indonesia memiliki rasa penasaran dengan janji yang juga memiliki bukti diberikan oleh perusahaan produk kecantikan brand Safi. Bukan hanya sekedar label halal, namun label tersebut yang menimbulkan rasa kepercayaan kepada perempuan Jakarta akan kandungan yang ada untuk terus menggunakan produk kecantikan yang diterbitkan oleh Safi Research Institute asal Malaysia tersebut.

\section{Simpulan}

Berdasarkan hasil dari penelitian di atas, kesimpulan yang dapat ditarik oleh peneliti adalah sebagai berikut: pertama produk yang memiliki label halal sulit ditemukan khususnya produk kecantikan atau skincare. Hal ini dikarenakan masih banyak perusahaan dari produk kecantikan yang tidak memperhatikan pentingnya memiliki label halal pada produk kecantikan, terutama produk kecantikan yang berasal dari Korea.

Kedua, produk kecantikan brand Safi tidak terlalu dikenal oleh masyarakat karena kurang berasosiasi dengan media konvensional seperti tv atau radio. Selain itu, sedikitnya pengetahuan perempuan Jakarta khususnya terhadap produk kecantikan brand Safi. Hal ini yang membuat skincare Safi belum terlalu dikenal oleh masyarakat walaupun sudah hampir satu tahun hadir di Indonesia.

Ketiga, label halal yang ada pada produk kecantikan brand Safi merupakan salah satu faktor dalam menarik minat beli perempuan terhadap skincare, karena 
kandungan yang terdapat membuat tidak khawatir terutama bagi para perempuan yang memiliki alergi terhadap bahan-bahan tertentu khususnya alkohol. Selain itu proses pembuatan suatu produk yang memiliki label halal tentu sangat terjamin keamanannya. Sehingga tidak menimbulkan keraguan terhadap perempuan Jakarta untuk menggunakan produk kecantikan memiliki label halal seperti Safi. Maka, dari penelitian ini dapat dilihat bahwa label halal yang ada pada produk kecantikan Safi menarik minat beli masyarakat.

\section{Ucapan Terima Kasih}

Peneliti mengucapkan terima kasih kepada seluruh narasumber yang telah bersedia untuk membantu memberikan waktu serta kerjasama dalam memberikan informasi selama proses penelitian ini berlangsung,. Ucapan terima kasih juga diberikan kepada berbagai pihak yang turut membantu dan mendukung peneliti menjalankan penelitian ini hingga selesai. Tidak lupa juga berterima kasih kepada pada dosen serta staf dari Fakultas Ilmu Komunikasi Universitas Tarumanagara yang membantu dari awal masa perkuliahan hingga penelitian ini telah diselesaikan dengan baik.

\section{Daftar Pustaka}

A. Muri Yusuf. (2014). Metode Penelitian Kuantitatif, Kualitatif \& Penelitian Bungin, Burhan. (2011). Penelitian Kualitatif. Jakarta: Kencana Predana Media

Creswell, J., W. (2012). Research design Pendekatan kualitatif, Kuantitatif dan Mixed; Cetakan ke-2. Yogyakarta: Pustaka Pelajar.

Kotler, Philip. (2009). Manajemen Pemasaran, Edisi 13. Jakarta : Erlangga.

Kotler, Philip dan Kevin Lane Keller. (2016). Marketing Managemen. Bandung: Pearson Education Inc.

Moleong, Lexy J. (2013). Metode Penelitian Kualitatif. Edisi Revisi. Bandung : PT. Remaja Rosdakarya.

Moh, Nazir. (2011). Metode Penelitian, Cetakan 6. Bogor : Penerbt Gahlia Indonesia. Sobur, Alex. (2017). Semiotika Komunikasi. Bandung : PT Remaja Rosdakarya.

Susanto, Eko Harry. (2010). Komunikasi Manusia Esensi dan Alikasi dalam Dinamika Sosial Ekonomi Politik. Jakarta : Mitra Wacana Media. 